\title{
IPARI SZÜRKEVÍZ VEGYSZERES KEZELÉSSEL ÉS BIOFILTERES SZÜRÉSSEL VALÓ TISZTÍTÁSÁNAK ÖSSZEHASONLÍTÓ ELEMZÉSE
}

\section{COMPARATIVE ANALYSIS OF INDUSTRIAL GREYWATER TREATMENT WITH CHEMICALS AND BIOSAND FILTRATION CLEANING}

\author{
Ungvári Levente ${ }^{1}$, Keczánné Üveges Andrea ${ }^{2}$ \\ ${ }^{1,2}$ Debreceni Egyetem Müszaki Kar Környezet- és Vegyészmérnöki Tanszék; 4028 \\ Magyarország Debrecen Ótemetö utca 2-4; \\ ${ }^{1}$ zaleilah6@gmail.com Telefon:+36/302514335 \\ 2 auveges@eng,unideb.hu
}

\begin{abstract}
In our research we investigated the physical and the chemical parameters of optical industry produced greywater from the point of recycling. Two different greywater treatment technologies were used: coagulation-flocculation, and biosand filtering. The colloidal contaminants stability in the greywater samples was determined from the zeta potential measurement results. Reduction was effectively identified in the turbidity and in the amount of the organic contaminants due to the effect of biosand filtering. High decrease was found in the amount of the colloid contaminants during coagulationflocculation.
\end{abstract}

Keywords: greywater, zeta potential, coagulation-flocculation, biosand filtration.

\section{Összefoglalás}

Kutatómunkánk során vizsgáltuk az optikai iparban termelődő szürkevíz fizikai és kémiai paramétereit újrahasznosítás szempontjából, melynek tisztításához két különböző szürkevíz kezelési technológiát alkalmaztunk: koagulálás-flokkulálás, biofilteres szürés. Kutatásaink során a zéta-potenciál mérésével kapott információkból következtettünk a kolloidális szennyezök stabilitására a szürkevíz mintákban. Megállapítottuk, hogy a biofilteres szürés hatására a szerves szennyezők mennyisége és a zavarosság csökkent hatékonyabban, míg a koagulációs-flokkulációs kezelés során pedig kolloid szennyezők mennyisége csökkent nagymértékben.

Kulcsszavak: szürkeviz, zéta-potenciál, koaguláció-flokkuláció, biofilteres szürés.

\section{Bevezetés}

Nemzetközileg meghatározott, hogy a fekete víz csak a WC-öblítésböl, míg a szürkevíz minden más háztartási célra használt vizet jelenti: mosogatásból, mosásból, zuhanyzásból, fürdésböl, kézmosásból származó vizeket [1]. Az újrahasznosításra szánt szürkevíz tisztító rendszereknek négy feltételnek kell megfelelniük: gazdasági megvalósíthatóság, esztétika, müszaki paraméterek jó beállítása, környezeti fenntarthatóság [2].

A vizek minőségére kaphatunk választ, ha a benne lévő szennyezőanyagok előfordulási formáit megvizsgáljuk. Mind a keze- 
lés, mind a felhasználás szempontjából fontos információkat kaphatunk [3]. A szenynyező anyagok vízzel szembeni magatartásuk szerint két csoportba sorolható: oldott és nem oldott anyagok [4].

A szennyeződést tartalmazó vizek vizsgálatakor felfedezhetőek kolloidális szenynyezők, melyek nem távolíthatók el egyszerủ szüréssel. A zéta-potenciál mérésével az oldatban jelenlévő kolloid rendszerek felületi potenciálját adhatjuk meg [5].

A koaguláció-flokkuláció, mint vegyszeres kezelés lényege, hogy a vízmintákhoz koaguláló-flokkulálószert adagolunk, amellyel a kolloid-diszperz állapotban levő részecskék destabilizációja és pelyhekbe tömörülése, a természetes szerves anyagok kicsapatása vagy adszorpciója biztosítható [6]. A koagulációs folyamatot nagymértékben befolyásolja az oldat $\mathrm{pH}$-ja, zéta-potenciálja és a koaguláns mennyisége. A módszert a szennyvíztisztításban is sikeresen alkalmazzák a lebegőanyagok eltávolítására, amely kb. 90\%-os hatékonysággal távolítja el azokat [7].

A biofilteres szürés Dr. David Manz munkásságához füződik, aki 1988-ban fejlesztette ki Kanadában a módszert ivóvíztisztításra [8]. A technológia egyszerü és gazdaságos, illetve környezetbarát, egészségre ártalmatlan, melynek során vegyszerrel nem találkozik a szürt víz. Adott méretü homokágyon biofilm réteget kell létrehozni, majd ezen a homokágyon átvezetve a vízmintát a mikroorganizmusok fejtik ki tisztító hatásukat. A biofilmnek a szuszpendált részecskék és a kórokozók eltávolításában van nagy szerepe [9].

\section{Anyag és módszer}

A szürkevíz mintákat a Carl Zeiss Vision Hungary Kft. mosodájának gyüjtőaknájából gyüjtöttük, amelyben több mosógépből származó mosóvíz elegyedett.

Mértük az általános fizikai-kémiai paramétereket, mint hőmérséklet, $\mathrm{pH}$, fajlagos elektromos vezetőképesség (Multiline P4 mérőbőrönd, WTW GmbH, Germany), a biológiai oxigénigényt (BOI) (OxiTop IS 12 manometrikus BOI-mérő WTW GmbH, Germany) a zavarosságot (Turb 555-IR, WTW GmbH, Germany).

A Debreceni Egyetem Környezet- és Vegyészmérnöki Tanszék Vízminőségvédelmi laboratóriumában az oldott szerves széntartalmat a Shimadzu TOC-VCPN, Shimadzu Corporation, Japan által gyártott készüléken határoztuk meg. A nyers és a kezelt vízmintákban a zéta-potenciált $(\zeta)$ a Malvern Instruments Ltd. által gyártott Zetasizer NanoZ készülék segítségével mértük.

A koagulációs-flokkulációs kezelésnél a kezelendő vízmintákhoz $\left(100 \mathrm{~cm}^{3}\right)$ adtuk hozzá a vegyszereket (vas(III)-klorid, alumínium-szulfát) automata pipetta segítségével. Ezt követően (ARE Heating Magnetic Stirrer) mágneses keverővel 30 másodpercen át kevertük a vegyszert tartalmazó szürkevizet 4-es fokozaton. Majd a kezelt szürkevizet $45 \mathrm{~cm}^{3}$ és $55 \mathrm{~cm}^{3}$ mintarészletre osztottuk. Az $55 \mathrm{~cm}^{3}$ kezelt mintából megkezdtük a zavarosság mérést és a DOC minta elökészítését, a $45 \mathrm{~cm}^{3}$ térfogatú mintát pedig 5 percen át ülepedni hagytuk. Az ülepedett mintából 2/3-ad magasságnál vettünk vízmintát fecskendő segítségével, majd a zéta-potenciál mérő kapillárisba töltöttük.

A biofilteres szüröt egy mindenki által élelmiszer tárolására is alkalmas PP anyagú hordóban állítottuk össze. A hordóba PVC anyagú vízvezeték csövet illesztettünk, amely a hordó aljára áramló szürt vizet vezeti ki hidrosztatikai nyomás hatására. A hordót alul kaviccsal töltöttük meg, $10 \mathrm{~cm}$ magasan, majd ezt követte a folyami homok, amelyet $40 \mathrm{~cm}$ magasságig töltöttünk a hordóba (1. ábra) A homokrétegen hoztuk létre a biofilmet. Ezt követően adagoltuk a tisztítandó mosóvizet, majd az átszürt tisztított vízből két literenként mintát vettünk, melynek paramétereit vizsgáltuk. 
Ipari szürkeviz vegyszeres kezeléssel és biofilteres szüréssel való tisztitásának összehasonlitó elemzése

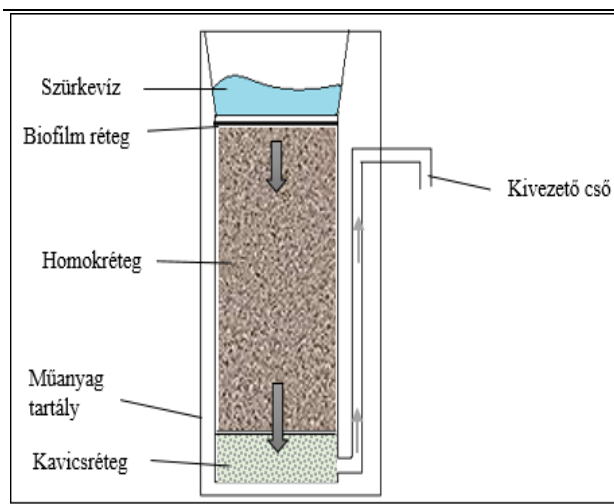

1. ábra. Biofilteres szürö felépitése

\section{Eredmények}

\subsection{Vegyszeres kezelés}

A koagulációs-flokkulációs kezeléskor vas(III)-kloriddal illetve alumíniumszulfáttal kezeltük az optikai iparban termelődő mosodai vizet (1. táblázat). Az optimális vegyszermennyiség meghatározásakor a kezelt részletre vonatkozóan vas(III)-klorid esetében $70 \mathrm{mg}$ vegyszerre volt szükség az izoelektromos pont eléréséhez $( \pm 5 \mathrm{mV})$, míg alumínium-szulfát esetében $75 \mathrm{mg}$ vegyszerre. A zéta-potenciál értéke vas(III)-klorid esetében $0,827 \mathrm{mV}$-ra csökkent, a zavarosság 82\%-kal csökkent, a DOC $42 \%-k a l$, míg a biológiai oxigénigény $76 \%$-kal a kezelés során. A vezetőképesség értéke a kezelés hatására emelkedett a kezdeti $1,53 \mathrm{mS} / \mathrm{cm}$-röl $2,01 \mathrm{mS} / \mathrm{cm}$-re. Az alumínium-szulfáttal történő kezeléskor a zéta-potenciál szintén a $0 \mathrm{mV}$ közelébe került, tehát nagymértékben sikerült eltávolítani a kolloidális méretü szennyezőket a kezelés során. A zavarosság mértéke ekkor 84\%-kal, a DOC 24\%-kal, míg a BOI értéke $76 \%$-kal csökkent a kezelés során. A vezetőképesség értéke ebben az esetben is emelkedett a kezelés során $1,53 \mathrm{mS} / \mathrm{cm}$-röl $1,80 \mathrm{mS} / \mathrm{cm}$-re. A pH mindkét esetben lúgos tartományból a savasba tolódott el, a vezetőképesség értéke pedig emelkedett a hozzáadott vegyszer hatására. 1.táblázat $A$ vegyszeres kezelés eredményei

\begin{tabular}{|c|c|c|c|}
\hline & $\begin{array}{c}\text { Zéta- } \\
\text { potenciál } \\
(\mathrm{mV})\end{array}$ & DOC $(\mathrm{mg} / \mathrm{l})$ & BOIs $\left._{5} \mathrm{mg} / \mathrm{l}\right)$ \\
\hline Kezelés elött & $-23,9$ & 246,5 & 330 \\
\hline $\begin{array}{c}\mathrm{FeCl} \\
\text { kezelés után }\end{array}$ & 0,827 & 144,9 & 80 \\
\hline $\begin{array}{c}\mathrm{Al}_{2}\left(\mathrm{SO}_{4}\right)_{3} \\
\text { kezelés után }\end{array}$ & 2,2 & 189,1 & 80 \\
\hline
\end{tabular}

A kezelést elvégeztük kereskedelmi forgalomban kapható koaguláló- és flokkuláló szerekkel. Két vegyszer alkalmazását próbáltuk, a vas-tartalmú (PIRAL-1) és polimerizált vas-tartalmú alumínium só (PIRAL-5) oldatokat. Az optimális vegyszermennyiség meghatározásakor $\sim 55,5 \mathrm{mg}$ $(0,30 \mathrm{ml})$ PIRAL-1 oldatra volt szükség $100 \mathrm{~cm}^{3}$ minta esetén. Ekkor a DOC értéke mindössze 13\%-os csökkenést mutatott. A PIRAL-1 esetében elmondható, hogy kevesebbre van szükség az izoelektromos pont eléréséhez, viszont a DOC csökkentésében nem olyan hatékony, mint az alkalmazott fémsók. A PIRAL-5 esetében $\sim 45 \mathrm{mg}$ $(0,15 \mathrm{ml})$ vegyszerre volt szükség az izoelektromos pont határának $( \pm 5 \mathrm{mV})$ eléréséhez. Ebben az esetben $26 \%$-kal csökkent a DOC értéke. Az optimális tömegek a PIRAL-1 és PIRAL-5 esetében is vas és alumínium tartalomra vonatkoztatva vannak megadva.

\subsection{Biofilteres szürés}

A biofilteres szürés hatására bekövetkező változások láthatóak a 2. táblázatban. A szürést követően a már átszürt vízből két literenként vettünk mintát, a mintarészletek 2-2 literre vonatkoznak. A szürés előrehaladtával a zéta-potenciál értékek emelkedtek, a vezetőképesség értékek csökkentek. Az oldott szerves széntartalom csökkenése minden átszürt mintában észlelhető volt. Az DOC csökkenésével pedig egyenes arányban csökkent a biológiai oxigénigény. Mind a BOI, mind a DOC hason- 
ló mértékben csökkent, mint fémsókkal $\left(\mathrm{FeCl}_{3}, \mathrm{Al}_{2}\left(\mathrm{SO}_{4}\right)_{3}\right)$ történő kezelés hatására. Ezzel szemben a zéta-potenciál a kezdeti csökkenést követően kismértékü, monoton növekedést mutatott a biofilteres szürés elörehaladtával. A zavarosság értékékek csökkentésében is egyértelmüen hatékonyabb volt a szürés (827,67 NTU-ról 7,00 NTU-ra csökkent) a fémsókkal való koagulációs kezeléshez képest. A vezetőképesség értéke pedig a vegyszerekkel való kezeléssel ellentétben csökkent (1,7 mS/cm-röl 1,3 mS/cm-re). A pH értéke vegyszeres kezelés során savas tartományba tolódott el, a biofilteres szürés hatására enyhén lúgos tartományba tolódott (6,9-ről 7,7-re).

\section{2. táblázat Biofilteres szürés eredményei}

\begin{tabular}{|c|c|c|c|}
\hline $\begin{array}{c}\text { Mintarészlet } \\
\text { száma }\end{array}$ & $\begin{array}{c}\text { Zéta- } \\
\text { potenciál } \\
(\mathrm{mV})\end{array}$ & $\begin{array}{c}\mathrm{DOC} \\
(\mathrm{mg} / \mathrm{l})\end{array}$ & $\begin{array}{c}\mathrm{BOI}_{5} \\
(\mathrm{mg} / \mathrm{l})\end{array}$ \\
\hline Eredeti & $-18,8$ & 217,4 & 375,0 \\
\hline 1. & $-10,2$ & 52,7 & 10,0 \\
\hline 2. & $-10,4$ & 36,1 & 10,0 \\
\hline 3. & $-10,8$ & 32,7 & 10,0 \\
\hline 4. & $-11,2$ & 33,5 & 20,0 \\
\hline 5. & $-12,8$ & 31,1 & 45,0 \\
\hline 6. & $-11,1$ & 81,5 & 90,0 \\
\hline 7. & $-13,4$ & 83,2 & 120,0 \\
\hline 8. & $-13,4$ & 98,5 & 120,0 \\
\hline 9. & $-14,9$ & 123,1 & 120,0 \\
\hline 10. & $-15,3$ & 100,1 & 125,0 \\
\hline
\end{tabular}

\section{Következtetések}

Optikai iparban termelődő mosodai víz kezelésében hatékonyabbnak bizonyult a vegyszeres kezelés során a $\mathrm{FeCl}_{3}$ (kolloidális szennyezök eltávolítása, vegyszerigény, DOC eredményesebben csökkent), szemben az alumínium-szulfáttal, PIRAL-1 és PIRAL-5-el. A leghatékonyabb módszer a szerves szennyezők eltávolításának szempontjából a biofilteres szürés volt. A $\mathrm{pH}$ vegyszeres kezelés hatására minden esetben savas irányba, biofilteres szürés esetében enyhén lúgos tartományba tolódott el.

\section{Köszönetnyílvánítás}

Az analitikai vizsgálatok elvégzését a TÁMOP-4.2.2.A-11/1/KONV-2012-0041 számú projekt támogatta. A projekt az Európai Unió támogatásával, az Európai Szociális Alap társfinanszírozásával valósult meg.

\section{Szakirodalmi hivatkozások}

[1] WHO, Guidelines for the safe use of wastewater, excreta and greywater use in agriculture, World Health Organization, vol. 4, 2006.

[2] Nolde, E., \& Dott, W. Verhalten von hygienisch relevanten Bakterien und Pilzen im Grauwasser-Ein ${ }^{-}$uss der UV-Desinfektion und Wiederverkeimung. gwf Wasser Abwasser, 1991., pp.108-114.

[3] Barkács K., Dr. Biczók Gy., Dr. Borossay J.: Vizminösités, vízkezelés. Szerkesztette: Ligetvári Ferenc, Szarvas, 2000.

[4] Husmann, W.: Szennyviztisztitás. Müszaki Könyvkiadó, Budapest, 1973.

[5] Patzkó Ágnes: Kolloidika Laboratóriumi gyakorlatok, Szegedi Egyetemi Kiadó, Szeged, 2012.

[6] Bányai István: Asszociációs kolloidok, oktatási segédanyag, Debrecen, 2015.

[7] Öllös Géza: Viztisztitás-üzemeltetés, Egri Nyomda Kft., Eger, 1998.

[8] Basu, O. \& Cleary, S. : BioSand/Slow Sand Filtration. University of Waterloo, ON. 2003.

[9] Kathleen Yung: Biosand Filtration: Application in the Developing World, University of Waterloo, 2003. 